УДК 614.447.6-027.45-004.413.4 (4) (476)

\title{
LEGAL BASIS FOR RISK ANALYSIS METHODOLOGY WHILE ENSURING FOOD SAFETY IN THE EURASIAN ECONOMIC UNION AND THE REPUBLIC OF BELARUS
}

\author{
E.V. Fedorenko \\ RUE “Scientific and Practical Center of Hygiene”, Republic of Belarus, Minsk, 8 Akademicheskaya St., 220012
}

Health risk analysis methodology is an internationally recognized tool for ensuring food safety. Three main elements of risk analysis are risk assessment, risk management and risk communication to inform the interested parties on the risk, are legislated and implemented in the Eurasian Economic Union and the Republic of Belarus. There is a corresponding organizational and functional framework for the application of risk analysis methodology as in the justification of production safety indicators and the implementation of public health surveillance. Common methodological approaches and criteria for evaluating public health risk are determined, which are used in the development and application of food safety requirements. Risk assessment can be used in justifying the indicators of safety (contaminants, food additives), and evaluating the effectiveness of programs on enrichment of food with micronutrients.

Key words: risk analysis, risk assessment, health, legal and regulatory framework, food safety.

The safety of food raw materials and food products is an issue of current interest in terms of public health. The economic damage from the most common food poisonings (of microbial and chemical nature) worldwide is estimated at hundred million dollars. Due to such social significance, food safety is a fast-growing medical filed that involves various economic industries. Taking into account that there are only few measures aimed at preventing a wide range of diseases associated with food products (micronutrient deficiency, food poisoning and intoxication of various origins) and that the cost of food safety ensuring measures, the use of qualitative assessment of the impact of individual harmful food-related factors on public health is of great importance.

In line with the approaches acknowledged on the international and European levels (Agreement on the Application of Sanitary and Phytosanitary Measures of the WTO [1], the CODEX Alimentarius Commission Standards [2], the EU Regulation №178/2002 of 28 January 2002 that set forth the general principles and requirements of the industrial law [3], the measures aimed at ensuring food safety should be realized with the application of risk analysis methodology.

The three interconnected elements of risk analysis - risk assessment, risk management, and public information about the risks - present a consistent method that can be used to identify effective, adequate, and targeted measures or actions aimed at ensuring consumer safety in terms of food products. Risk assessment is a scientific expert methodology that helps scientists measure the level of risk to public health associated with potentially harmful food-related factors - contaminants, pathogenic microorganisms, accessory food substances, and enriching ingredients. The data on health risk assessment is used to validate and regulate the management decisions on food safety (risk management). The information on risk, if necessary, is provided to the interested parties - product manufacturers, state agencies, consumers (informing about the risk).

The current legislation of the Eurasian Economic Union contains risk assessment elements. Appendix 12 "Protocol on the Application of Sanitary, Veterinary-Sanitary, and Phytosanitary

(C) Fedorenko E.V., 2015

Fedorenko Ekaterina Valeryevna - Candidate of Medicine, Associate Professor, Head of the Laboratory studying the population nutritional status (e-mail: afedorenko71@ mail.ru; tel. +375 1728413 70). 
measures" to the Agreement on the Eurasian Economic Union defines risk assessment as the key tool of sanitary-antiepidemiological activities aimed to reduce or eliminate such risk, prevent the contraction and spread of infectious and mass noninfectious diseases (restrictions) and their elimination, which by definition is risk management [4].

The word "risk" in the legislation of the Eurasian Economic Union is not specific to food products and, in general, corresponds to the approved international views on the discussed area. Appendix 9 "Protocol on Technical Regulation within the Eurasian Economic Union" to the Agreement on the Eurasian Economic Union defines risk as a combination of the probability of harm and the consequences of this harm impacting human life and health (in terms of sanitary and epidemiological well-being of the residents) [4].

The Regulation About Sanitary-and-Epidemiological Supervision (Control) on Customs Border of the Customs Union adopted by the Decree of the Customs Union Commission on May 28, 2010 № 299 technically captures in legislation the approaches to the management of food-related risks used by the agencies authorized in sanitaryand-epidemiological well-being, as well as informing about the risk [5].

The Customs Union Technical Regulation on Food Safety TR TS 021/2011establishes that safety of food products is the condition of food product indicating the absence of inadmissible risk connected with adverse health effects on humans and future generations [6].

The Belarus Law of January 7, 2012 №340-Z About the Sanitary and Epidemiological WellBeing of the Population established that all the anti-epidemiological activities - organizational, preventative, and other activities aimed to assess the risk of adverse health effects connected with environmental factors, eliminate or reduce the impact 17]. Article 19 of the above law and the Regulation About the Social-and-Hygienic Monitoring, adopted by the Decree of the Ministry of health of the
Republic of Belarus of July 17, 2012 №105 [8] establishes the objectives of social-and-hygienic monitoring in the form of identifying the levels of risks to human life and health and developing the activities aimed to prevent, reduce and eliminate adverse health effects connected with the environmental factors. Some objectives of social-andhygienic monitoring in the Republic essentially form the methodology of risk analysis (Table 1).

A new version of the bill "On quality and safety of food raw materials and food products for the life and health of humans" has been recently introduced in the Republic of Belarus; it contains the main definitions - "risk", "risk analysis" and its component and proposes to use risk analysis when exercising the state control and supervision in the sphere of food product safety [9].

The functional model of the use of the above methodology in the Republic of Belarus is shown in Figure 1 below.

The methodology for assessing health risks associated with food products is an essential component of risk analysis that receives a lot of attention from researchers from the EEU members and the Republic of Belarus. The methodology for assessing health risks associated with the chemical,

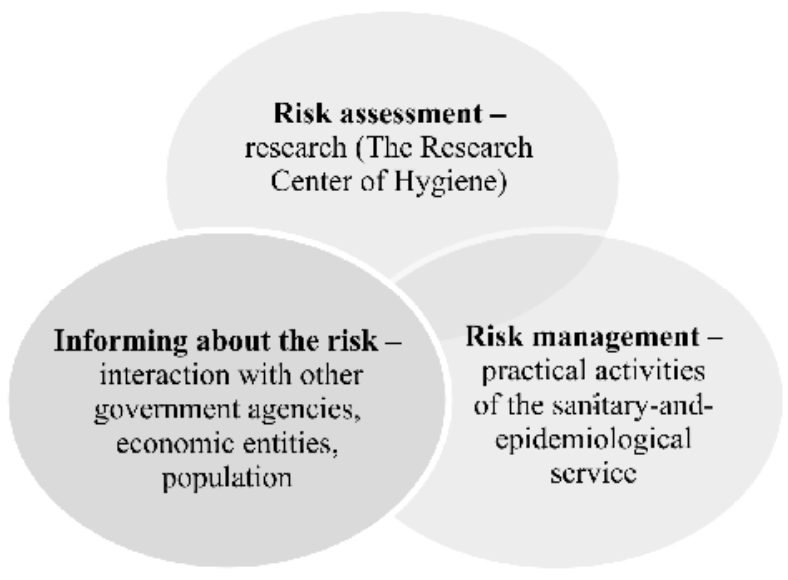

Figure 1. Model on the application of risk analysis methodology when ensuring the safety of food products in the republic of Belarus

Statutory individual components of risk analysis in the Republic of Belarus [8]

\begin{tabular}{|c|c|c|}
\hline Risk assessment & Risk management & Informing about the risk1 \\
\hline $\begin{array}{l}\text { Identify the factors affecting human } \\
\text { health through determining the caus- } \\
\text { al relationship between the state of } \\
\text { health and environmental condi- } \\
\text { tions; } \\
\text { Making forecasts about the state of } \\
\text { health }\end{array}$ & $\begin{array}{l}\text { Validate, develop and organize the implementation } \\
\text { of the programs aimed to ensure the sanitary-and- } \\
\text { epidemiological well-being and public health safe- } \\
\text { ty; } \\
\text { Prepare drafts for the state authorities to help them } \\
\text { take measures to eliminate the detected hazardous } \\
\text { environmental factors }\end{array}$ & $\begin{array}{l}\text { Coordinate inter-departmental com- } \\
\text { munication; } \\
\text { Inform the state agencies, organiza- } \\
\text { tions and physical persons, including } \\
\text { individual entrepreneurs, about the } \\
\text { monitoring results. }\end{array}$ \\
\hline
\end{tabular}


physical, and biological factors for the purpose of identifying the indicators of safety of food products (goods) developed by the EEC in cooperation with the Russian Federation, the Republic of Belarus, and the Republic of Kazakhstan establishes a uniform approach and criteria for the assessment of public health and will be used in the development and application of the requirements to food safety [10]. This direction of joint work is very essential since according to the Agreement on the Eurasian Economic Union [4], the application of domestic hygienic standards on food product safety that are different from the ones adopted in the Eurasian Economic Union is not possible.

Now therefore, the methodology for assessing health risks is generally implemented in the legislation and guidelines of the Eurasian Economic Union - uniform methodological approaches have been established 110], risk management and informing about the risk are carried out in accordance with [5].

Application of risk assessment to ensure the safety of food products is pursuant to the Agreement on the Eurasian economic Union [4] and is mandatory for all the WTO state members. WTO Agreement Article 5 on the application of sanitary and phytosanitary measures reads: "Members shall ensure that their sanitary or phytosanitary measures are based on an assessment, as appropriate to the circumstances, of the risks to human, animal or plant life or health, taking into account risk assessment techniques developed by the relevant international organizations" [1].

Overall, the methodology of risk assessment as a scientific expert methodology in the sphere of ensuring the safety of food products may be used as follows:

To validate the criteria of safety of food products in relation to the biological agents, chemical substances - contaminants, accessory food substances, pesticides, assessment of safety and effectiveness of micronutrient deficiency programs;

To rate the facilities in terms of the supervisory activities based on a range of factors depending on the risks to consumers' health associated with the manufactured products;

To locate the facilities and identify the sanitary protection zones at the stage of warning sanitary supervision.

The Republic of Belarus now uses new methodological approaches brought in accordance with the international standards to determine the algo- rithm and criteria for the assessment of health risks created by the presence of contaminants, biological agents, and accessory food substances in food products.

As for safety criteria, Belarus uses the hygienic standards adopted by the Eurasian Economic Union. The methodology of risk assessment is used to evaluate the iodine deficiency programs [11]. And assess the safety of some accessory food substances $[12,13]$.

The iodine deficiency program has been working in the republic of Belarus since 2000; one of its components is mandatory use of iodized salt when making industrially manufactured food products (except for products from sea-fish, seafood). Provided such circumstances, there is a possibility that some consumers may consume biologically active components in the amount that exceed the upper exposure level. For this reasons, a quality health risk assessment was conducted to assess the level of risk associated with excessive consumption of iodine by adults.

Various scenarios of consumption of micronutrients with meals were validated with the account for the level of iodine in food products, average and high levels of consumption of food products, and share of enriched products in the market. The obtained results showed that mass food products (baked goods, sausage goods) manufactured with iodized salt promote adequate provision of iodine in residents and does not result in excessive consumption even in aggravated scenarios. The obtained results showed that mandatory enrichment of mass food products with iodine in the form of iodized salt is safe [11].

Reliability of the hygienic regulations concerning the application of accessory food substances was assessed in relation to nitrates. Consumption of nitrates with meals was assessed within a realistic scenario as well as for individuals with high levels of consumption of sausage goods - dangerous sources of the discussed chemical substances. The obtained results showed no excess of permissible daily consumption of nitrates for adults with normal levels of consumption of sausage goods. However, when aggravated models were used, alimentary exposure to nitrates was significant which indicated the presence of unacceptable risk for such consumers. At the same time, such load was formed not so much by the use of accessory food substances, as by the level of consumption of food 
products in the manufacturing of which they are used [12].

To summarize, overall the methodology of risk analysis in ensuring the safety of food products in the Eurasian Economic Union and the Republic of Belarus is established in the law; there is a relevant functional framework for its realization, specific work is carried out to develop and improve consistent methodological approaches to health risk assessment among the residents exposed to the chemical, physical and biological factors to ensure the safety of food products.

\section{List of references}

1. The WTO Agreement on Sanitary and Phytosanitary Measures / World Trade Organization [Electronic resource]. - 2011. - Mode of access: http://www.wto.org. - Date of access: 20.03.2015.

2. Codex Alimentarius Commission. Working principles for risk analysis for food safety for application by governments / WHO Food Standards Programme, Food and Agriculture Organization of the United Nations [Electronic resource]. - Mode of access: http://www.codexalimentarius.org/download/standards/394/CXG_50e.pdf. Date of access: 20.03.2015.

3. Regulation (EC) no 178/2002 of the European Parliament and of the Council of 28 January 2002 laying down the general principles and requirements of food law, establishing the European Food Safety Authority and laying down procedures in matters of food safety / Access to European Union law [Electronic resource]. - 2014. Mode of access: http://eur-lex.europa.eu/legal-content/EN/TXT/PDF/?uri=CELEX:32002R0178\&qid= 1429076106145. Date of access: 20.03.2015.

4. Agreement on the Eurasian Economic Union. Eurasian Economic Commission [Electronic resource].2015. - Access mode : http://www.eurasiancommission.org/ru. - Date of access: 01.04.2014.

5. Regulation on a procedure of state sanitary-and-epidemiologic supervision (control) over persons and vehicles, crossing customs border of customs union, of goods under control, moved through customs border of customs union and on customs territory of customs union / Комиссия Таможенного союза [Electronic resources]. 2010. - Access mode: http://www.tsouz.ru/db/techregulation/sanmeri/Documents. - Date of Access: 30.03.2015.

6. On Food Safety (TR TS 021/2011): Customs Union Commission [Electronic resource]. - 2014. - Access: http://www. eurasiancommission.org/ru/db/techreglam/Documents/TR\%20TS\% 20bezopProd.pdf. - Date of Access: 01.04.2015.

7. On the Sanitary-and-Epidemiological Well-being of the Population: Law of the Republic of Belarus of January 7, 2012 №340-3 / Ministry of Health of the Republic of Belarus [Electronic resource]. - 2015. Access mode: http://minzdrav.gov.by/ru/static/acts/normativnye/zakony. - Date of access: 01.04.2015.

8. Regulation on the Procedure of the Social-and-Hygienic Monitoring / Ministry of Health of the Republic of Belarus [Electronic resource]. - 2015. - Access mode: http://minzdrav.gov.by/ru/static/ acts/normativnye/postanovlenia_ ministerstva/o-sotsialno-gigienicheskom-monitoringe_i_1612.html. - Date of access: 30.05.2015

9. On the Quality and Safety of Food Raw Materials and Food products for the Life and Health of People: Law of the Republic of Belarus of June 29, 2003. №217-3 / Ministry of Health of the Republic of Belarus [Electronic resource]. - 2015. - Access Mode: http://minzdrav.gov.by/ru/static/acts/normativnye/zakony. - Date of Access: 01.04.2015.

10. The Methodology to Assess Health Risks Associated with the Chemical, Physiological, and Biological Factors to Identify the Safety Indicators for Food Products (Goods). - M. : Umanite Media, 2014. - 120 p.

11. Evaluation of Iodine Deficiency Programs in the Republic of Belarus / N.D. Коломиец // Zdorovie i Okruzhauschaya Sreda: collection of research papers / Ministry of Health of the Republic of Belarus; the Republican Scientific and Practical Center of Hygiene; chief editor S.I. Sychik. - Minsk: Republican Scientific Library, 2014. - Vol. 2, Iss. 24. - P. 170-173.

12. Fedorenko, Ye.V. Hygienic assessment of the alimentary load by the accessory food substances (case study: nitrates) / E Ye.V. Fedorenko, O.V. Shulyakovskaya, L.V. Bordak // Zdorovie i Okruzhauschaya Sreda [Electronic resource]: collection of research papers / Ministry of Health of the Republic of Belarus, the Republican Scientific and Practical Center of Hygiene, Belarussian Scientific Society of Hygienists; editorial staff: L.V. Polovinkin (chief editor) [et al]. - Minsk, 2014. - Iss. 21. - P. 617-623.

13. Fedorenko, Ye.V. Approaches to the assessment of the alimentary load of accessory food substances / Ye.V. Fedorenko, N.D. Kolomiets // Gigiena i Sanitariya. - 2013. - № 1. - C. 40-41. 